\title{
The Current Situation, Problems and Path Selection of "Machine Replacing People" in the Manufacturing Industry of Dongguan*
}

\author{
Huimin Song \\ City College of Dongguan University of Technology \\ Dongguan, China 523000
}

\author{
Feihu Shen \\ Dongguan Third People's Hospital \\ Dongguan, China 523000
}

\begin{abstract}
The promotion of "machine replacing people" is an inevitable choice for Dongguan's industrial transformation and upgrading. Using machines to replace people is the way. Industrial transformation and upgrading is the purpose. Dongguan's manufacturing industry has to implement "machine replacing people" at present. "Machine replacing people" has achieved some results in Dongguan over the past few years. However, there are still many problems, such as lack of funds for the technical transformation of projects, little use of equipments manufactured in Dongguan, imperfect participation ways of the productive service industry and lack of $R \& D$ skilled personnel. In order to give full play to the role of "machine replacing people" in the transformation and upgrading process of Dongguan's manufacturing industry, it is necessary to help enterprises relieve capital pressure, accelerate the development of intelligent equipment industry in Dongguan, promote the integration of the productive service industry and the manufacturing industry, and develop various talents for "machine replacing people".
\end{abstract}

Keywords-Dongguan; manufacturing industry; "machine replaces people"; upgrading of industrial structure

\section{INTRODUCTION}

In the current Internet age, Industry 4.0 has become the development trend of manufacturing industries in the world. The German government proposed the "Industry 4.0" strategy in 2013 to increase the competitiveness of German industry and take the lead in the new round of industrial revolution. "Industry 4.0" is the fourth industrial revolution led by intelligent manufacturing. The manufacturing industry is an important part of China's industries. Its transformation and upgrading under the new economic situation has always been highly valued by the government. First, the government proposed China Made 2025. China will use 10 years to surpass

* [CLC No.] F424.7 [Document code] A

[Fund Program] City College of Dongguan University of Technology Young Teachers Development Fund "Research on Problems and Countermeasures of "Machine Replacing People" in Dongguan's Manufacturing Industry" (201605); City College of Dongguan University of Technology 2016 Innovation School Project Teaching Reform Project "Research on Micro-class Design of Advanced Financial Accounting Based on Situational Teaching"; City College of Dongguan University of Technology 2017 -2018 Annual Quality Project Key Course Program "Advanced Financial Accounting".
Germany and Japan, and by 2025 become the biggest and most powerful industrial country in the world. This requires the traditional manufacturing industry to achieve transformation and upgrading as soon as possible and to become the industry with an advanced level. Second, the government will carry out structural reforms on the supply system. Compared with the expansion of demand, structural reforms on the supply system mainly focuses on improving the quality and efficiency of the supply system, reducing the operating costs of enterprises, reducing tax burdens, and strengthening the drive for sustained economic growth. Labor, land, capital, and innovation are the four major factors of the supply system. The structural reforms on the supply system will inevitably lead to the increase and decrease of the four major factors. The capital (including production factors) to replace part of the labor force is the development trend in the current era, so that the "machine replacing people" came out, setting off a wave of reforms in Dongguan.

\section{ANALYSis OF THE STATUS OF "MACHINE REPLACING PEOPLE" IN DONGGUAN'S MANUFACTURING INDUSTRY}

\section{A. "Machine Replacing People" Policy Measures}

In September 2014, Dongguan City issued the "machine replacing people" policies, including "Implementation Opinions on Accelerating the Development of Industrial Robot Intelligent Equipment Industry in Dongguan", "Dongguan's Action Plan for Promoting "Machine Replacing People"" and "Management Approaches for the Specific Fund of "Machine Replacing People" in Dongguan". There are also other supporting policies such as "Implementation Plan of Dongguan 3C Industry Intelligent Manufacturing Demonstration Projects", "Opinions of Developing Robot Intelligent Equipment Industry and Building Advanced Manufacturing Base with Global Impact" and "Development Plan for Dongguan's Intelligent Equipment Industry (20152020)". These policies can be classified into the following four categories: First, provide financial support for "machine replacing people". There are four flexible methods to manage the "machine replacing people" special fund: afterward reward, providing loans, equipment rental subsidies and loan interest subsidy. Second, promote the development of Dongguan's intelligent equipment industry. Third, strengthen platform 
support. Fourth, promote the integration of science and technology, finance, and industry.

\section{B. Equipment Selection and Funding Sources}

In 2015, 881 "machine replacing people" projects were declared, with a total investment of 7.003 billion yuan, of which 1.266 billion yuan was used for the equipments produced in Dongguan, which accounted for $18 \%$, and the proportion is relatively low. Most of the projects are small and medium-sized and invested in fixed assets. There are 312 projects with the investment of 3 million yuan or less, accounting for $35.4 \%$; 186 projects with the investment of 3 to 5 million yuan, accounting for $21.1 \%$, the number of the two is 498, accounting for 56.5 . \%; There are 178 projects with the investment of 5 to 10 million yuan, accounting for $20.2 \%$; 172 projects with the investment of 10-30 million yuan, accounting for $19.5 \%$; 33 projects with the investment of more than 30 million yuan, accounting for $3.7 \%$. The funds needed for the "machine replacing people" project are frequently several million or even tens of millions. The project not only tests the investment level of companies, but also tests the financing capacity of companies. Self-owned funds, bank loans, and equipment leasing are the most common financing models. The self-owned funds can be carried out by retaining earnings or issuing new shares. The equipment leasing is in the form of financial leasing. The funding costs of different funding sources are also different.

\section{The Participation of Productive Service Industry}

The productive service industries related to "machine replacing people" mainly include: financial insurance, technology research and development, industrial design, professional technical services, information transmission services and software services, leasing and business services, accounting, legal, management consulting, human resource services, etc.

According to the participation stage, the productive service industries are mainly divided into three categories: the project implementation productive service industry, the project effectiveness evaluation productive service industry, and the declaring government's special funds productive service industry.

\section{Personnel Needs of "Machine Replacing People" Project}

After the completion of the 881 projects declared in 2015 , it is estimated that 46600 people will be replaced, and the labor productivity will increase from $92.04 \%$ to $97.23 \%, 1.66$ times of the original labor productivity. Machines are to replace those who lack professional skills, do repetitive work or do hazardous work. New talents who can operate, maintain, and upgrade equipments will be needed. Such personnel are generally intermediate or senior technicians. But Dongguan lacks such talents.

\section{ANALYSIS OF THE PROBLEMS OF "MACHINE REPLACING PEOPLE" IN DONGGUAN'S MANUFACTURING INDUSTRY}

\section{A. Lack of Funds for Technical Transformation of Projects}

Although the willingness of enterprises to upgrade equipments and technologies has increased, it requires a onetime investment of several million yuan or even tens of millions of yuan to purchase automation equipments. This is not a big pressure for large companies with sufficient funds, but is a pressure for small and micro enterprises. They don't have the ability to take out so much money and they are in urgent need of loans. Small and micro enterprises often don't have enough credit and lack effective collateral. It is difficult for them to obtain large-amount and long-term loans from banks, and private financing is also costly. Enterprises have to move a large sum of money from cash that is not sufficient for intelligent transformation. Moreover, it may occur that the new equipment that has just been purchased by the company will become obsolete again after two or three years of use. Enterprises will have to update their equipments and face financial pressure once again.

\section{B. Little Use of Equipment Produced in Dongguan}

In Dongguan's robotics industry, companies with the production value of 50 million yuan or less account for $70 \%$ of all companies, and only two companies have the production value of more than 500 million yuan, accounting for less than $1 \%$. The companies are usually small and there is no leading enterprise in the industry. The low competitiveness of equipments produced in Dongguan mainly manifests itself in the following aspects: The development of core intelligent components and complete machines are not in sync; the overall technological innovation capability of the industry is much behind that of foreign countries; important basic technologies and key components rely much on others; there are hidden risks of overcapacity in part of the industries; there is lack of statistical and industry standards; and the research and development capability is weak.

\section{The Participation Mode of the Productive Service Industry Needs to Be Guided and Improved}

The advantages of the productive service industry's participation are as follows: First, "machine replacing people" is a very professional project. Some productive service companies play an important role in the "machine replacing people" process; second, productive service companies can increase the success rate of special subsidy declaration, shorten the declaration period, and promote the "machine replacing people" policy. Third, the participation of the productive service industry is conducive to promoting the development of the technical service industry. The disadvantages of productive service industry's participation are: First, the charges for the productive service industry will reduce the incentive effect of the special subsidies; Second, there may be counterfeiting actions, which may reduce the reliability of the application materials; and third, there may be some corporate personnel who use rights to do rent-seeking behavior. 
As an important part of the market, the productive service industry has played a role in the promotion of the "machine replacing people" policy in Dongguan using its professional advantages. However, it is not that the more participation of the productive service industry, the better. The way in which it participates in "machine replacing people" needs to be improved and guided.

\section{Lack of R\&D Skilled Personnel}

Dongguan lacks first-class colleges and universities, and does not have the ability to independently cultivate $R \& D$ talents. The necessary talents are basically introduced from outside. Compared to Guangzhou, Shenzhen, and other developed cities, Dongguan is relatively backward in terms of social environment, entrepreneurial environment, and academic atmosphere. It is less attractive to high-level talents, has lower carrying capacity for high-level talents, and is at a disadvantage of personnel competition.

Dongguan also lacks skilled workers. At present, the ratio of senior, middle and junior technical personnel in Dongguan is 1.45:3.14:6.41. There are few senior and mid-level skilled personnel, and there are many junior skill talents. The domestic advanced cities such as Suzhou, Wuxi and Changzhou have more than $25 \%$ senior skilled personnel, almost $50 \%$ middle-level skilled personnel, the senior and middle-level technicians account together for more than $75 \%$. Dongguan's figure is only about $42 \%$, which is far behind advanced cities.

\section{The Optimization Paths of "MAChine REPLACING PEOPLE" IN DONGGUAN'S MANUFACTURING INDUSTRY}

\section{A. Relieve the Financial Pressure of Companies' "Machine Replacing People"}

Establish a multi-level, diversified, multi-channel financing system for the "machine replacing people" project to promote the cooperation of financial industry and "machine replacing people" project in the manufacturing industry, encourage various financial institutions to innovate financial products, improve financial services, and provide preferential credit support for the "machine replacing people" project, achieving flexibility in fundraising. Strengthen the communication between banks and manufacturing enterprises, encourage banks to provide credit support for companies that implement "machine replacing people", streamline loan approval processes, and improve service efficiency; the government should make full use of its credibility and coordination functions to organize various bank-enterprise communication activities, strengthen the bank-enterprise cooperation, effectively solve the problems in the bank-enterprise cooperation, create a good financial environment, actively recommend key projects of "machine replacing people" to banks, encourage banks to lower the threshold for superior projects and provide loan support for them. Implement the state's tax policy that supports the development of advanced manufacturing, advanced equipments and intelligent manufacturing equipments, and reduce the burden on enterprises through tax means.

\section{B. Accelerate the Development of Dongguan's Intelligent Equipment Industry}

The intelligent equipments produced in Dongguan should be more advanced, which requires more funding and policy support. The funding standard for equipments produced in Dongguan is $15 \%$ of the equipment investment. This proportion can be maintained or appropriately increased to attract the interest of "machine replacing people" companies in equipments produced in Dongguan, thereby stimulating the development of the intelligent equipment industry in Dongguan. Establish a special fund for the development of intelligent manufacturing industry and guide enterprises to increase investment in $R \& D$.

The establishment of the intelligent manufacturing standards system can support the development of the industry. Enterprises with industry-leading capabilities should be encouraged to formulate the industry standard system. Encourage leading companies to set standards for themselves and set common standards together. Increase funding for formulating standards and adopting standards.

\section{Promoting the Coordinated Development of Productive Service Industry and Manufacturing Industry}

The productive service industry can promote the improvement of the efficiency of the manufacturing industry and has a significant spatial spillover effect. Accelerate the integration of manufacturing industry and productive service industry, provide system and policy guarantee for the integration of productive service industry and manufacturing industry, and promote the coordinated development of the two industries.

There is a serious shortage of $R \& D$ technical productive service companies in Dongguan, and productive service companies cannot meet the demand of manufacturing industry for industrial development and innovation. With the transformation and upgrading of manufacturing industry, the industry's demand for high-quality, high-efficiency and specialized R\&D productive services has risen sharply. However, the supply of relevant services in Dongguan is insufficient, and the productive service industry's enthusiasm for innovation is not high. Related industries cannot form regional clusters to develop rapidly, and cannot meet the demand of the manufacturing industry.

Dongguan has a large number of accounting service companies. Most of them play the role of declaring intermediary in the "machine replacing people" process, failing to embody financial and taxation expertise. First of all, such companies should continue to provide high-quality accounting and auditing services. Second, they should be encouraged to participate in manufacturing enterprises' equipment investment decisions and financing project decisions. Finally, accounting service companies should provide professional financial and taxation consulting services for manufacturing enterprises to increase their corporate value. 


\section{Training Various Talents Required for "Machine}

\section{Replacing People"}

Establish a talent flow mechanism among the government, universities, scientific research institutions, and enterprises, and create a good human resource environment. Strengthen talent introduction and attract talents in productive service industry at home and abroad. Through the introduction and training of talents and comprehensive development, meet the demand for composite talents in the new productive service industry and support the sustainable development of the industry.

Develop vocational and technical education and training. In accordance with the industrial development needs of Dongguan, vigorously develop vocational and technical colleges and adjust major settings in a timely manner. The vocational and technical colleges shall, based on the principles of "sufficient theories for use, emphasis on practice" and "applying theories to practice", innovate the training mode and improve the level of personnel training. Increase government support, improve the vocational and technical education and training system, and build a domestic advanced vocational education and training base. Further increase the openness of vocational and technical education and training schools, encourage domestic and provincial prestigious vocational and technical schools to set up branch schools or training bases in Dongguan, and make local colleges such as Dongguan University of Technology and Dongguan Polytechnic play their roles.

\section{CONCLUSION}

The manufacturing industry is the foundation, characteristic, and advantage of Dongguan's economic and social development. Promoting "machine replacing people" is an inevitable choice for Dongguan's industrial transformation and upgrading. "Machine replacing people" is the way. Industrial transformation and upgrading is the purpose. "Machine replacing people" has promoted the transformation and innovation of management methods such as production management, human resource management, and informationbased management, and has made the organization finer and more systematic. Dongguan should also face the problems in the process of "machine replacing people", so that can effectively promote the transformation of enterprises from "manufacturing" to "intelligent manufacturing".

\section{REFERENCES}

[1] Song Huimin, Shen Feihu. Cost-benefit analysis of ABC company's "machine replacing people" project. Friends of Accounting. 2017 (22) 宋慧敏、申飞虎. $\mathrm{ABC}$ 公司 “机器换人” 项目成本效益分析. 会计之 友.2017(22)

[2] National Bureau of Statistics. Third National Economic Survey, 2014. 国家统计局.第三次全国经济普查, 2014. 